\title{
Molecular characterization of katA from Campylobacter jejuni and generation of a catalase-deficient mutant of Campylobacter coli by interspecific allelic exchange
}

\author{
Kathleen A. Grant and Simon F. Park \\ Author for correspondence: Simon F. Park. Tel: +44 1734 357227. Fax: +44 1734267917.
}

Institute of Food Research, Reading Laboratory, Earley Gate, Whiteknights Road, Reading, RG6 2EF, UK

\begin{abstract}
A gene encoding catalase (hydrogen-peroxide:hydrogen-peroxide oxidoreductase; EC 1.11.1.6) from Campylobacter jejuni was cloned by functional complementation of a catalase-deficient mutant of Escherichia coli. The catalase structural gene, designated katA, was assigned by subcloning and its nucleotide sequence determined. The deduced protein product of 508 amino acids, which had a calculated molecular mass of $58346 \mathrm{Da}$, was found to be structurally and enzymically similar to hydrogen-peroxidases from other bacterial species. The region of DNA containing the structural catalase gene was disrupted by insertion of a tetracycline-resistance marker and the modified sequence then introduced into a strain of Campylobacter coli via natural transformation. Genetic and enzymic analyses of a tetracyclineresistant C. coli transformant confirmed that catalase-deficient mutants had arisen via interspecific allelic exchange. Compared to the isogenic parental strain the mutant was more sensitive to killing by $\mathrm{H}_{2} \mathrm{O}_{2}$.
\end{abstract}

Keywords: Campylobacter jejuni, Campylobacter coli, catalase, kat $A$, gene replacement

\section{INTRODUCTION}

Campylobacter jejuni and Campylobacter coli are now considered to be the major bacterial cause of human diarrhoeal disease in Britain and probably the developed world (Tauxe, 1992). These Gram-negative, spiral-shaped bacteria are described as being microaerophilic and generally require low levels of $\mathrm{O}_{2}$ and increased $\mathrm{CO}_{2}$ concentrations for their growth. The inability of $C$. jejuni and $C$. coli to grow in air is thought to be related to their hypersensitivity to the toxic products of $\mathrm{O}_{2}$ metabolism (Hoffman et al., 1979a, b). Clearly, the lack of tolerance of these organisms towards $\mathrm{O}_{2}$ must place serious constraints upon their survival in foods and in environments where they are likely to encounter oxidative stress. However, it is apparent that both $C$. jejuni and $C$. coli are able to survive in food in sufficient numbers to cause infection since this is the main vehicle of their transmission (Griffiths \& Park, 1990; Humphrey, 1992). In this context, there are now a number of reports describing aerotolerance in Campylobacter spp. (Vercellone et al., 1990; Jones et al., 1993) and

The GenBank accession number for the nucleotide sequence reported in this paper is $X 85130$. it has even been suggested that Campylobacter can adapt to an aerobic metabolism (Jones et al., 1993). It is obvious that prolonged aerobic survival of campylobacters, or indeed any organism, must involve mechanisms through which they are able to eliminate the deleterious effects caused by the generation of toxic $\mathrm{O}_{2}$ derivatives. In this respect catalase, which catalyses the dismutation of $\mathrm{H}_{2} \mathrm{O}_{2}$ to $\mathrm{H}_{2} \mathrm{O}$ and $\mathrm{O}_{2}$, is considered to be part of a defence system against oxidative stress and, accordingly, is present in most aerobic organisms. In addition, because macrophage killing is associated with a respiratory burst that involves the generation of $\mathrm{H}_{2} \mathrm{O}_{2}$ and superoxide, the antioxidative effects of catalase are thought to make an important contribution to the survival of several bacterial pathogens during infection (Mandell, 1975; Haas \& Goebel, 1992).

As a first step to defining the role of catalase in the survival of $C$. jejuni and $C$. coli under conditions of oxidative stress, we describe the cloning and phenotypic expression of the gene (kat $A$ ) encoding catalase, from $C$. $j e j u n i$, in Eschericbia coli. In addition, a copy of the $C$. jejuni structural catalase gene, disrupted by the insertion of an antibiotic marker, was used to transform a strain of $C$. coli to a catalase-negative phenotype demonstrating the oc- 
currence of allelic exchange between DNA originating from two separate species of Campylobacter. In order to assess the role of catalase in the oxidative stress resistance of Campylobacter spp., the $C$. coli catalase-deficient mutant was compared with the isogenic parental strain with respect to their sensitivity to $\mathrm{H}_{2} \mathrm{O}_{2}$.

\section{METHODS}

Bacterial strains and media. Campylobacter jejuni NCTC 11351 and other strains of $C$. jejuni were obtained from the National Collection of Type Cultures (Colindale) and grown microaerophilically as described previously (Purdy \& Park, 1994). The strain Campylobacter coli UA585 was a generous gift from D. E. Taylor (University of Alberta, Edmonton, Canada). E. coli UM255, a catalase double mutant, was kindly provided by P. C. Loewen (University of Manitoba, Canada). E. coli strains were grown at $37^{\circ} \mathrm{C}$ on LB agar supplemented with $100 \mu \mathrm{g}$ ampicillin $\mathrm{ml}^{-1}$ when necessary.

Construction and screening of a C. jejuni genomic library. Chromosomal DNA from C. jejuni was extracted according to the method of Pitcher et al. (1989) and partially digested with HindIII. Fragments of 3-7 kb in size were purified from an agarose gel and ligated into the cloning vector PTZ19R (Pharmacia) using standard procedures (Maniatis et al., 1982). The library was introduced into E. coli UM255 by electroporation (Dower $e$ t al., 1988) and cells plated on to LB agar supplemented with ampicillin. Transformants were screened for catalase activity by flooding the plates with $3 \% \mathrm{H}_{2} \mathrm{O}_{2}$ and looking for colonies producing bubbles of $\mathrm{O}_{2}$. Colonies exhibiting catalase activity were then rapidly transferred to fresh agar plates.

DNA analysis. Plasmid DNA from colonies containing the recombinant catalase gene was isolated by miniprep and the gene assigned by subcloning (Maniatis et al., 1982) to a recombinant plasmid termed pCKG2, which contained a $1.8 \mathrm{~kb}$ HindIII DNA fragment derived from C. jejuni. To facilitate nucleotide sequencing the insert in PCKG2 was cut into three smaller fragments with $E_{c o} \mathrm{RI}$ and ligated into pTZ19R. DNA sequencing was performed on an Applied Biosystems model 373A DNA sequencing system. A Taq Dye Deoxy Terminator Cycle Sequencing kit (ABS) was used to generate fluorescencebased dideoxysequence reactions containing pCKG1 and its derivatives as template. Primers were designed to bind to opposing strands at approximately $200 \mathrm{bp}$ intervals to allow sequence data to be obtained from both strands separately. Nucleic acid and protein and sequence data were analysed using the Wisconsin molecular biology software package (Devereux $e t$ al., 1984).

Protein extraction and enzymic analysis. In order to characterize the protein product of the cloned $C$. jejuni catalase gene and the enzymic activity of a $C$. coli catalase-deficient mutant, total cell proteins, prepared as described previously (Purdy \& Park, 1994), were analysed by SDS-PAGE (Laemmli, 1970). To demonstrate the expression of catalase activity protein samples were resolved on $7.5 \%(w / v)$ polyacrylamide gels, under nondenaturing conditions, and then assayed for catalase activity in situ using the ferricyanide-negative stain described by Woodbury et al. (1971). Staining for 3,3'-diaminobenzidine-peroxidase activity was as described by Wayne \& Diaz (1986).

Allelic exchange and natural transformation. The kat $A$ sequence present in $\mathrm{pCKG} 2$ was disrupted by the introduction of a $2 \cdot 3 \mathrm{~kb}$ BglII tetracycline-resistance cassette (Dickinson $e$ t al.,
1995) into the unique $B g / \mathrm{II}$ site at position 1145 (Fig. 1). The resulting plasmid, pCKG3, was introduced into $C$. coli UA585 by natural transformation (Wang \& Taylor, 1990). Transformants were recovered after $48 \mathrm{~h}$ following microaerophilic incubation at $37^{\circ} \mathrm{C}$ on Mueller-Hinton agar (MHA) containing $10 \mu \mathrm{g}$ tetracycline $\mathrm{ml}^{-1}$.

DNA/DNA hybridizations. Genomic DNA, isolated from both wild-type and a catalase-deficient mutant of $C$. coli, was digested with various enzymes and electrophoresed on a $0.7 \%$ agarose gel. Following depurination with $250 \mathrm{mM} \mathrm{HCl}$, the DNA was transferred from the gel to a Hybond $\mathrm{N}+$ nylon membrane (Amersham) using $0 \cdot 4 \mathrm{M} \mathrm{NaOH}$. Hybridizations were performed using a non-radioactive ECL gene detection kit (Amersham) according to the manufacturer's instructions using the purified insert from $\mathrm{pCKG} 2$ as a gene probe.

$\mathrm{H}_{2} \mathrm{O}_{2}$ sensitivity assay. Cell suspensions, prepared from overnight cultures of $C$. coli UA585 or CK100 on agar plates, were inoculated into pre-warmed Mueller-Hinton broth to an $\mathrm{OD}_{600}=0 \cdot 3 \cdot \mathrm{H}_{2} \mathrm{O}_{2}$ was added to a final concentration of $1 \mathrm{mM}$ and cells incubated microaerophilically at $37^{\circ} \mathrm{C}$. During the course of the experiment the ability of cells to replicate was assessed by plating diluted aliquots onto MHA plates containing bovine catalase $\left(100 \mathrm{U} \mathrm{ml}^{-1}\right)$. At the same time the concentration of $\mathrm{H}_{2} \mathrm{O}_{2}$ remaining in the media was determined using the peroxidase/phenol red assay (Pick \& Keisari, 1980).

\section{RESULTS}

\section{Cloning of katA from C. jejuni by complementation of $E$. coli UM255}

Phenotypic complementation of the E. coli double catalase mutant UM255 (Mulvey et al., 1988) was used as a screen to identify derivatives of a $C$. jejuni genomic library that contained potential catalase genes. Screening of approximately 5000 transformants yielded eight clones which produced bubbles of $\mathrm{O}_{2}$ when exposed to $3 \% \mathrm{H}_{2} \mathrm{O}_{2}$. All eight of these derivatives were later found to contain an identical $4 \mathrm{~kb}$ insert of $C$. jejuni DNA (data not shown). To facilitate further characterization of the putative catalase gene, one derivative, designated pCKG1, was digested with HindIII, and the resulting fragments ligated into $\mathrm{pTZ19R}$. The recombinant plasmids were transferred into $E$. coli UM255 and the transformants screened for catalase activity. In this manner, the gene encoding the putative catalase was assigned to a $1.8 \mathrm{~kb}$ HindIII fragment present in a plasmid designated pCKG2.

\section{Nucleotide sequence analysis of the $k a t A$ gene}

The nucleotide sequence of the $1.8 \mathrm{~kb}$ fragment of $C$. jejuni DNA in PCKG2 was determined. This sequence was found to contain an unterminated ORF. It was assumed, therefore, that the HindIII site used to generate this fragment was internal to the $3^{\prime}$ end of the catalase gene. Consequently, the sequence of the $3^{\prime}$ terminus of the gene was determined using PCKG1 as a template as this plasmid was predicted to contain an intact ORF. Accordingly, the ORF in pCKG2 was found to extend beyond a HindIII site, present at position 1838, and internal to the termination codon for the intact gene (Fig. 1). The region of DNA encoding the catalase activity was 


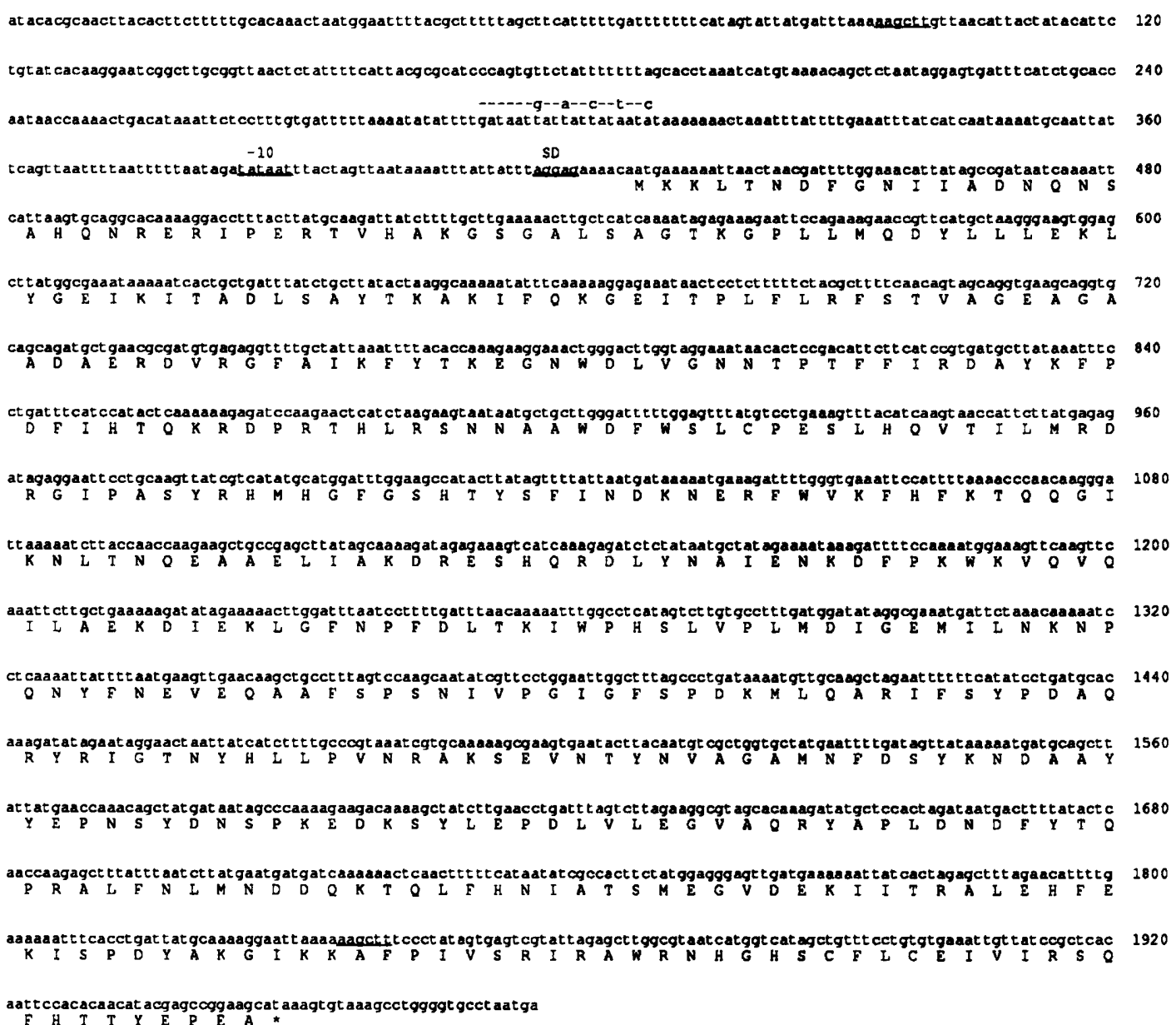

Fig. 1. Nucleotide sequence of the $C$. jejuni NCTC 11351 katA gene. The nucleotide sequence of a 1978 bp region of pCKG1 is shown. The predicted amino acid sequence is shown below the nucleotide sequence and the termination codon is represented by an asterisk. A potential ribosome-binding site (SD) and a putative -10 promoter region are underlined. The region which shows high homology to the Fur protein binding sequence is also shown above the nucleotide sequence. Conserved nucleotides are represented by dashes. Recognition sites for the restriction enzyme HindIII are underlined.

found to contain an ORF of 1521 bp (designated kat $A$ ) with the potential to encode a 508 amino acid protein with a predicted molecular mass of $58346 \mathrm{Da}$ (Fig. 1). A putative ribosome-binding site (AGGAG; Gold, 1988) exists $6 \mathrm{bp}$ upstream of the ATG start codon. A potential -10 region (conserved in all six residues; Hawley \& McClure, 1983) of an E. coli consensus promoter sequence was present $37 \mathrm{bp}$ upstream of this point although no sequence with homology to the corresponding -35 region was apparent. However, the sequence GATAATtATtATtATaATa, which starts at nucleotide position 292, matches 14 of 19 nucleotides found in the consensus sequence for Fur-binding sites involved in the transcriptional regulation of iron-repressible genes (de Lorenzo et al., 1987; conserved residues shown in uppercase). The $\mathrm{G}+\mathrm{C}$ content of the coding region is $33 \%$, which is consistent with the average $\mathrm{G}+\mathrm{C}$ content for DNA from Campylobacter species (Belland \& Trust, 1982).

A search of the GenBank database revealed that the predicted protein product of the kat $A$ gene had an extensive degree of homology to catalases from various sources (Fig. 2). The highest degree of homology was seen with bacterial hydroperoxidases, there being $65 \%$ identity with Brucella abortus catalase (Sha et al., 1994), $60 \%$ identity with Bordetella pertussis catalase (DeShazer et al., 1994), $58 \%$ identity with Haemopbilus influenzae $\mathrm{HktE}$ catalase (Bishai et al., 1994) and $54 \%$ identity with Bacillus subtilis Kat19 catalase (Bol \& Yasbin, 1991). In addition, the predicted $C$. jejuni catalase protein was found to be $42 \%$ identical to the E. coli HP II catalase (von Ossowski et al., 1991).

\section{Expression and enzymic activity of the cloned $C$. jejuni katA gene product in $E$. coli}

To determine the size of the proteins specified by the derivative plasmids containing the cloned $C$. jejuni kat $A$ gene, total cell proteins from the various plasmidcontaining strains were analysed by SDS-PAGE. Cells containing the plasmid pCKG1 produced a $57.5 \mathrm{kDa}$ 
1 ... WKLTNCFGNI I ADNONSLSAGTKGPLLMODYLILEKLA

Cj. .......WKKLTNDFGNI IADNQNSLSAOTKGPLLMQDYLIIEKLA

BP. . . . MNAMTNKTITTARGAFVADNNNTMT AGFPGFALLQDVWFLEXLA

Hi. MSEQCPFSHLAATNITMGNGAFVADINQNSLTAGFFGFLLAQDLWLNEXLA

Ba. MKLQEDYSMTDRFIMTYSAGATIFDNQNSLTAGEROFILMQDYQLIERLS

BS. . . . . M MSSNKLTTSWGA FVGDNQNSMTAGSFGPTLIODVHLLEKLA

Ec. . . . . . . ITTNQGVRIADDONSIRAGSFGTFLLEDFILFEXIT

51 100

Cj. HQNFEFIPERTVHAKGSGAYOEIKITADLSAYTKAKIF. QKGEITFLFLR Bp. HFDERR I PERYUAYGSGAYGTFTVTHDI SRYTTARIFAEVGFOTPLFLR Hi. DFVEEVIPERAMHAKGSGAFOTFTVTHDITKYTKAKIFSEVGKKTEMFAR Ba. HQNFEFIPERAVHALGWGAYGLIIIGDISPYTKAKVL. QPGAQT PMLAR BS. HFNFEEVPERVVHA:GZGALGYFEVTNDVTKYTKA.AFLSEVGKRTFIFIR EC. HFDHERIPERIVHAPGSAAYOYFQFYKSLSDITHADFLSDPNKITFVFVR

101 150

Cj. ISTVAGEAGALDAERDVRGPAIXFYTREGNIDLVGNNTPTPFIFDAYKFP BP. TSTVIGERGAADAERDIRGFAIXFYTDEONWDLVGNNTPVFFIFDFLKFP

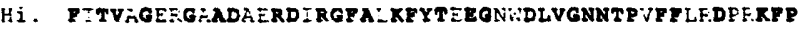

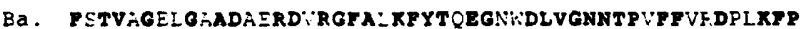
BS. FCTVIGELGSADT URDFRGFAUKPYTEEGNYDIVGNTPUTEIEDAIKFP EC. FSTVQGGLGADTVRDIRGFATKFYTEEGIFDLVGNNTIFPIQDAHKFP

151 200

C $j$. DFIHICRRDPRTHLRSNNAA . . WOFWSLCPESLHQVTILMPDRGIPAS BP. DFIHTCKEDPKTNLENATAA . . . WDFWSLNPESLHQVTILMSDRELPQN Hi. DLNKAVKRDPRTNMRSATNN. . . WDFWTLLPEALHQVIVIMSDRGI PAS Ba. DFIHTQRFYPRTHLRSATAM. . . MDFWSLSPBSLHQVTILMSDRELFTD BS . DFIHTQKFDRKTHLKNFTAV . . . WDFWSLSPESLHQVTILMSDREIPAT EC. DFVHAVXPEPHWAI FQGQSAHDTFWDYVSLGPETLHNVMWAKSDRGIPRS

201 250

Cj. YRHYHGFOSHTYSF ZNDKNERFWVHFHFKTQQGIKNLTNQEAAELIAKDR

BP. YRQQHGFCSBTY SFVNDAGERFYVKFHFKSQQGIACYTDGEAAELVGRDR

Hi. YRHNHGFGSBTYSFWNEAGERFWVKTHFKTQQGIKNLTDAEAAEIIANDR

Ba. VRHINGVOSHTYSFWNDAGERYWVYPHEKTMQGHKHWTNAEAEQVIGRTR

BS. IRHMHOFOSHTFKVINAEPEGVWIKYHFKTEQGVKNLDVNTAAKIAGENP

EC. YRTMEGFGIBTFRLINAEGKATFVRFHWKPLFOKASLVWDEAOKLTGRDF

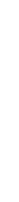

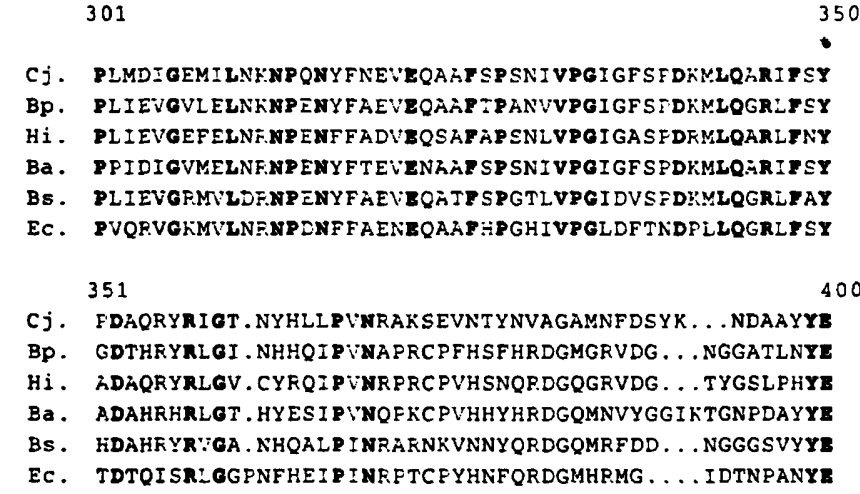

401

Cj. PYSYDNSPKEDKSYLEPDLVLEG . VAQRYA. PLDN . . . . DFYTQPRAL

BP. PNSFGEW. REAYHAAEP PLALDGQAADRWNHRVDE. . . . . DYYSQPGAL

Hi. PKSFSOW . QQQFDFAEP PLRISGDAA. HWDYRTDDN . . . DYFSQPRAL

Ba. PNBFNGP.VEQPSAKEP PLCISGN . ADRYNHRIGN . . . . DDYSQPRAL

BS. PWSFGG. PKESPEDKQAAY PVQGIADSVSYDHYDH . . . . . . YTQAGDL

EC. PNSINDNWPRETPPGPKRGGFESYQERVEGNKVRERSPSFGEYYSHPRLF

451

500

Cj. FNLMNDDQKTQLFHNIATSMEGVD. EKIITRALEHFEKISPDYAKGIKKA

BP. FRLMNDDQKQQLFGNIGRHMAGVP. EEIQRRQLEHFRRADPAYAAGVAKA

Hi. FNLMNAEQKQSLFNNTAAAMGDAP. DFIKYRHIRNCHWCDAAYGEGVAKA

Ba. FNLFDAAQKQRLFSNIAAAMKGVP.GFIVERQLGHFKLIHPEYEAGVRKA

BS. YRLMSEDERTRLVENIVNAMKPVEKEEIKLRQIEHFYKADPEYGKRVAEG

EC . WLSQTPFEQRHIVDGF SFELSKVVRFYIFERVVDQLAHI DLTLAOAVAKN

501

cj. FPIVSRIRAWRNHGHSCFLCEIVIFSOFHTTYEPEA. . . . . . .

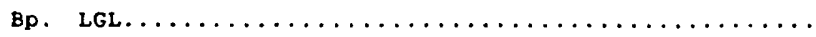

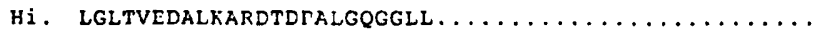

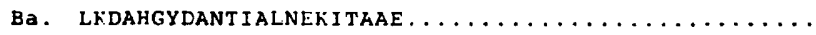

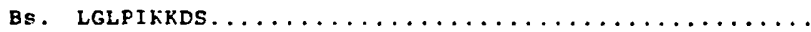

EC. LGIELTDDQLNITPPPDVNGLKKDPSLSLYAI PDGDVKGRVVAILLNDEV

251

Cj. ESHQR DLYNAIENKDFPKWKVQVQILAEKDIEKLGFNPFDLTRIWPHSLV

BP. ESAQRDLFQNIEQGQFPRWTLKVQVMPEAEAATYHINPFDITKVWPHADY

Hi. ESHQRDLYEAIERGDFPKWTLFVQTMFEADAEKVFYHFFDLTXVWSKKDY

Ba. ESTQELLFSAIENGEFP KWKVQVQIMPELDADKTFYNPFDLTKVWPHADY

BS. DYHTEDLFNAIENGDYPAWKLYVQIMPLEDANTYKFDEFDVTXVWSOKDY

EC. DFHRFELWEAIEAGDFPEYELGFQLIPEEDEFKFDFDLLDFTKLIPEELV

Fig. 2. Comparison of the catalase from $C$. jejuni with those from other bacterial species. The derived amino acid sequence from the $C$. jejuni katA gene (Cj) is aligned with that from B. pertussis $(\mathrm{Bp}), H$. influenzae $(\mathrm{Hi}), \mathrm{B}$. abortus $(\mathrm{Ba})$, $B$. subtilis (Bs) and $E$. coli (EC). Residues conserved between all six enzymes are shown in bold.

protein that was not seen in cells containing the parental vector pTZ19R (Fig. 3). The size of this protein is very similar to that predicted for the product of the kat $A$ gene and it is most likely that this band represents KatA. In contrast, the plasmid pCKG2 uniquely specified a $60 \mathrm{kDa}$ protein (Fig. 3). This is consistent with the nucleotide sequence data, which shows that the ORF is incomplete and reads into the plasmid-derived lac $Z$ gene. It is likely, therefore, that this band represents a protein in which a truncated KatA is fused, via its C-terminus, to $\beta$ galactosidase. The calculated size of the fusion protein, which is $62 \mathrm{kDa}$, is in good agreement with this.

To confirm that KatA did indeed possess catalase activity, lysates from $E$. coli recombinants were analysed by nondenaturing PAGE and stained for catalase activity. As expected no bands of catalase activity were seen in lysates from strain UM255 harbouring the parental vector pTZ19R (Fig. 4). In contrast, when pCKG1 was present in UM255 a single band of catalase activity was apparent. The achromatic band of catalase activity specified by pCKG2 appeared to be the result of protein that was larger than that produced by pCKG1 (Fig. 4). Again, this result is consistent with this protein being a KatA- $\beta$ galactosidase fusion. It is interesting to note that, although this protein lacks 38 amino acids from the C-terminus of the catalase, it is still enzymically active. When protein extracts from C. jejuni were analysed for catalase activity, in a similar fashion, a single band of catalase was evident. The $R_{F}$ value for this band of activity was equivalent to that specified by $\mathrm{PCKG1}$ in $E$. coli, suggesting that the same catalase enzyme is responsible for the production of 
A

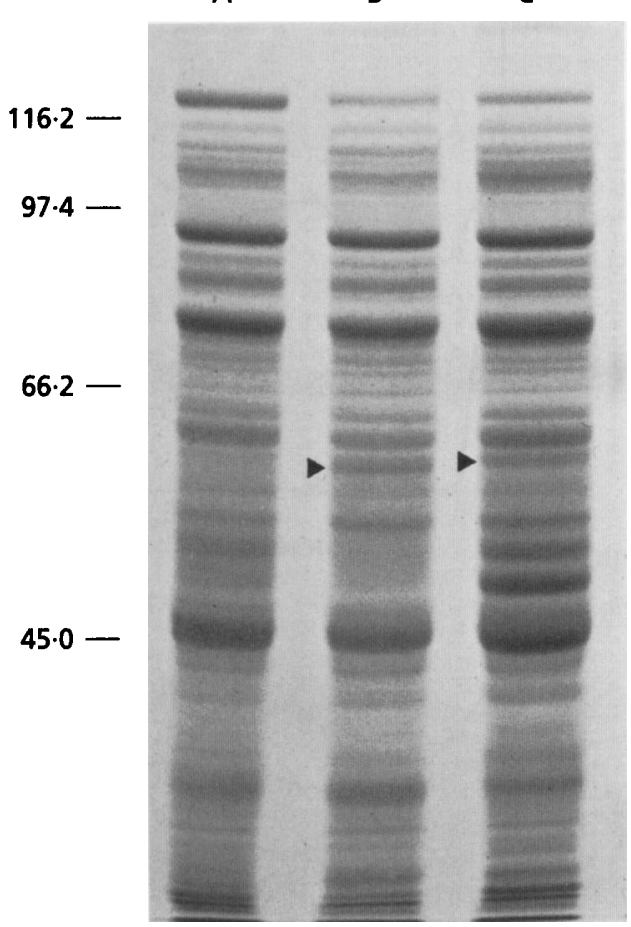

Fig. 3. Expression of the catalase from C. jejuni in E. coli. Total soluble proteins from recombinant strains of $E$. coli UM255 were analysed by electrophoresis on $10 \%$ SDS-PAGE gels and visualized by Coomassie blue staining. Lanes: A, lysate from cells containing pTZ19R; B, lysate from cells containing pCKG1; C, lysate from cells containing pCKG2. Molecular mass standards are given in $\mathrm{kDa}$ and proteins produced uniquely from specific plasmids are indicated by arrows.

both bands. To determine whether or not KatA also possessed peroxidase activity, equivalent non-denaturing PAGE gels were assessed for 3,3'-diaminobenzidineperoxidase activity as described by Wayne \& Diaz (1986). Proteins with peroxidase activity generally stain black against a light background. No bands of staining were detected for any protein sample, including one prepared from C. jejuni (data not shown).

\section{Generation of a catalase-deficient mutant of $C$. coli by interspecific allelic exchange}

As a first step towards constructing isogenic catalasedeficient mutants the structural $C$. jejuni catalase gene present in pCKG2 was distupted by the insertion of a $B g l \mathrm{II}$ tetracycline-resistance cassette into the unique $B g l \mathrm{II}$ site at position 1145 (Fig. 1) to generate pCKG3. The strain C. jejuni NCTC 11351 from which kat $A$ was originally cloned has proven refractory to the introduction of recombinant DNA either by electroporation or natural transformation (unpublished data) and is, therefore, an unsuitable host for the construction of mutants via gene replacement. The opportunity arose, therefore, to determine whether pCKG3, containing DNA derived from $C$. jejuni, could be used to generate a catalase-

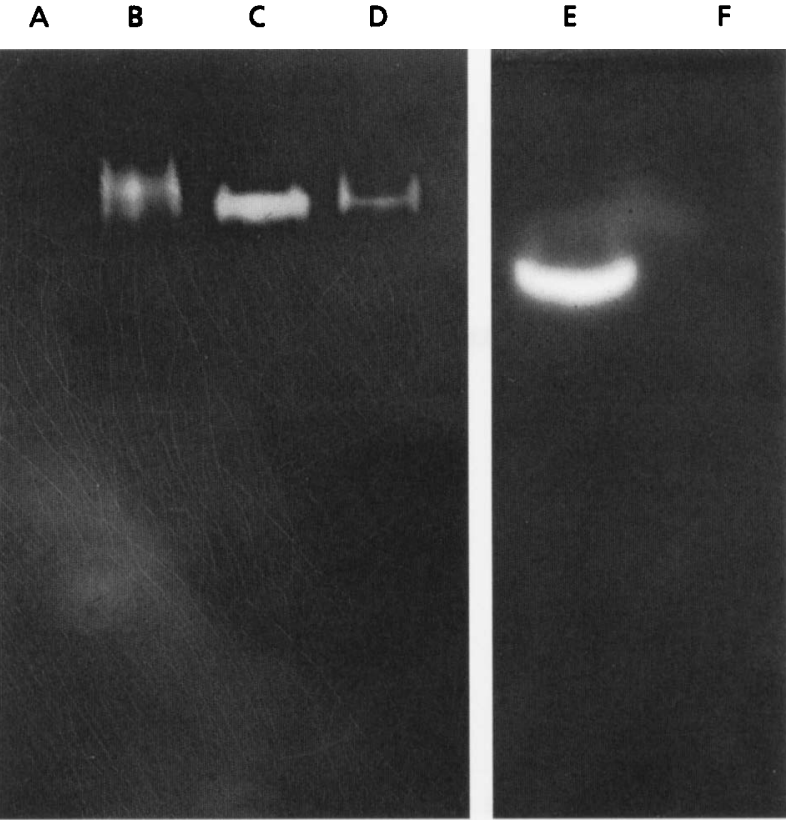

Fig. 4. Non-denaturing polyacrylamide gels stained for catalase activity. Total soluble proteins were analysed by electrophoresis on $7.5 \%$ polyacrylamide gels run under non-denaturing conditions and visualized following specific staining for catalase activity. Catalase activity appears as an achromatic band against a dark background. Lanes: $A$, lysate from $E$. coli cells containing pTZ19R; B, lysate from E. coli cells containing pCKG2; C, lysate from $E$. coli cells containing PCKG1; D, lysate from $C$. jejuni NCTC 11351; E, lysate from C. coli UA585; F, lysate from C. coli CK100. (Note that lanes $E$ and $F$ represent a separate gel so the mobility of the achromatic band should not be compared with those in other lanes.)

deficient mutant of $C$. coli via interspecific allelic exchange. Accordingly, pCKG3 was introduced into C. coli UA585 by natural transformation. Tetracycline-resistant transformants were obtained with a low frequency (up to 20 transformants per $\mu \mathrm{g}$ DNA).

\section{Genetic and phenotypic characterization of C. coli katA isogenic mutants}

To examine the phenotype of the tetracycline-resistant colonies, catalase activity was assessed using the qualitative plate assay. Approximately $50 \%$ of the transformants exhibited a catalase-negative phenotype consistent with allelic exchange resulting from a double crossover recombinational event. In the catalase-positive transformants it is likely that integration of pCKG3 had occurred via a single crossover which would regenerate an intact copy of the catalase structural gene (Dickinson $e t$ al., 1995). To confirm the nature of the genetic event which led to the catalase-deficient phenotype, a DNA fragment containing the kat $A$ gene (the $1.8 \mathrm{~kb}$ insert in pCKG2) was labelled and hybridized to digested total DNA extracted from one $\mathrm{Kat}^{-} C$. coli transformant designated CK100. For the DNA from the parental strain of $C$. coli the probe hybridized to single EcoRV and ClaI 


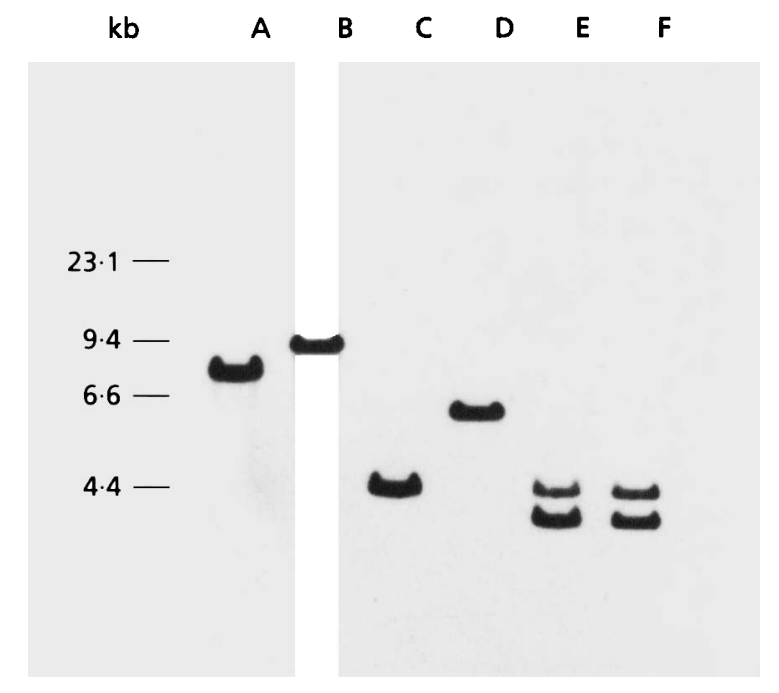

Fig. 5. Southern analysis of CK100, a tetracycline-resistant $\mathrm{Kat}^{-}$ transformant. A Hindill fragment from pCKG2 was labelled and used to probe genomic DNA isolated from: C. coli UA585 digested with EcoRV (lane A), Clal (lane C) and Bg/ll (lane E), and C. coli CK100 digested with EcoRV (lane B), Clal (lane D) and Bg/ll (lane F). Molecular size standards are shown in kb.

fragments (Fig. 5). This is expected since there are no sites for these enzymes internal to kat $A$. For CK100, however, although the probe hybridized to single bands in the EcoRV and ClaI digests, the size of these fragments was $2.3 \mathrm{~kb}$ larger when compared to the wild-type. This is consistent with the exchange of the wild-type kat $A$ DNA with the disrupted sequence present in pCKG3, containing the $2.3 \mathrm{~kb}$ tetracycline-resistance marker. Digestion of the DNA with $B g l \mathrm{II}$ produced the same pattern of hybridization in the DNA from both mutant and wildtype cells. Again this is expected if allelic exchange has occurred, since the $B g l$ II tetracycline-resistance marker cassette, internal to the disrupted kat $A$ gene in the mutant strain, will be released and the regions of DNA which flank this site will be unchanged relative to the wild-type DNA. No hybridization occurred between the labelled plasmid backbone (pTZ19R) and DNA from CK100 (data not shown) confirming the loss of the nonhomologous plasmid-derived sequence during allelic exchange. To confirm the Kat ${ }^{-}$phenotype of CK100, lysates from the strain were analysed by non-denaturing PAGE and stained for catalase activity. Although a single band of catalase activity was apparent in lysates from the isogenic parental strain of $C$. coli no achromatic bands were seen in lysates prepared from the mutant (Fig. 4).

\section{$\mathrm{H}_{2} \mathrm{O}_{2}$ sensitivity of $\mathrm{Kat}^{+}$and $\mathrm{Kat}^{-} \mathrm{C}$. coli}

To assess the contribution of the catalase, encoded by kat $A$, in the oxidative stress resistance of $C$. coli the sensitivity of the wild-type strain and CK100 (Kat $\left.{ }^{-}\right)$to $\mathrm{H}_{2} \mathrm{O}_{2}$ was assessed. In $1 \mathrm{mM} \mathrm{H}_{2} \mathrm{O}_{2}$ the survival of the parental $\mathrm{Kat}^{+}$strain decreased by $50 \%$ over the first (a)
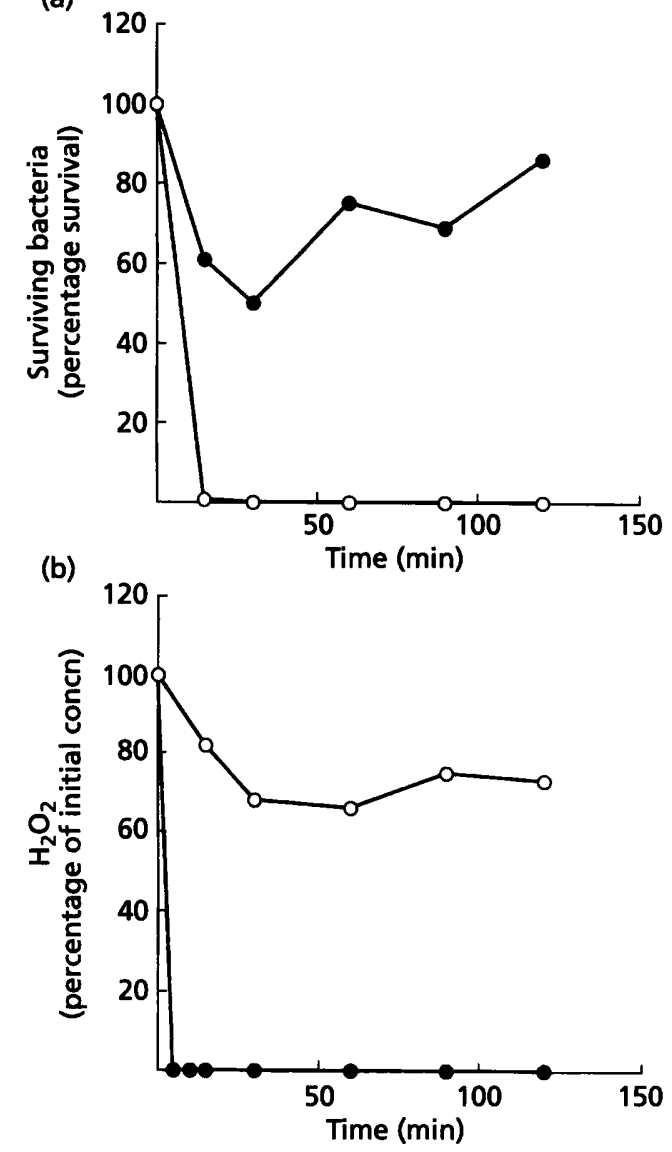

Fig. 6. $\mathrm{H}_{2} \mathrm{O}_{2}$ sensitivity of $\mathrm{C}$. coli UA585 $\left(\mathrm{Kat}^{+}\right)$and $\mathrm{CK} 100\left(\mathrm{Kat}^{-}\right)$. (a) Cells of $\mathrm{C}$. coli UA585 (O) and CK100 (O) were exposed to $1 \mathrm{mM} \mathrm{H}_{2} \mathrm{O}_{2}$ and the percentage survival determined from viable counts. (b) The persistence of $\mathrm{H}_{2} \mathrm{O}_{2}$ in the growth media during the survival of $C$. coli UA585 (G) and CK100 (O) was also determined. Similar results were reproducibly obtained in several experiments.

$30 \mathrm{~min}$, after which point cell growth appeared to resume (Fig. 6). In contrast, the survival of the $\mathrm{Kat}^{-}$mutant dropped to just $0.8 \%$ after the first $15 \mathrm{~min}$ and thereafter was undetectable (less than 10 c.f.u. $\mathrm{ml}^{-1}$ ). To determine whether the destruction of $\mathrm{H}_{2} \mathrm{O}_{2}$ by catalase or the persistence of this microbicidal agent could account for the difference in resistance of the wild-type cells compared to $\mathrm{Kat}^{-}$cells, $\mathrm{H}_{2} \mathrm{O}_{2}$ concentration was assessed during the survival studies. In the presence of $\mathrm{Kat}^{+}$cells the concentration of $\mathrm{H}_{2} \mathrm{O}_{2}$ fell to undetectable levels (less than $1 \mu \mathrm{M}$ ) after just $5 \mathrm{~min}$. Conversely, when $\mathrm{H}_{2} \mathrm{O}_{2}$ was exposed to $\mathrm{Kat}^{-}$cells its concentration fell gradually to $68 \%$ of the original level over the first $60 \mathrm{~min}$ and then did not decrease further over the next $60 \mathrm{~min}$.

\section{DISCUSSION}

Catalases, which degrade $\mathrm{H}_{2} \mathrm{O}_{2}$ to $\mathrm{H}_{2} \mathrm{O}$ and $\mathrm{O}_{2}$, are present in most aerobic organisms and are considered to be part of a defence system against oxidative stress (Haas \& Goebel, 1992). In this study we describe the cloning of 
a gene (kat $A$ ) encoding catalase from the microaerophilic pathogen $C$. jejuni.

The product of the $C$. jejuni kat $A$ gene appeared as a $57.5 \mathrm{kDa}$ protein in recombinant strains of $E$. coli, which was in close agreement to the predicted kat $A$ gene product of $58.3 \mathrm{kDa}$. The amino acid sequences of a number of bacterial catalases have now been deduced and most have been found to share homology with eukaryotic haem-catalases (von Ossowski et al., 1993). The notable exception is the E. coli HPI catalase. This is not surprising, however, since it possesses both a catalase activity and broad-range peroxidase activity (Claiborne \& Fridovich, 1979). The amino acid sequence of KatA from $C$. jejuni showed no homology to HPI but considerable homology to the group of bacterial hydroperoxidases. Moreover, although hydroperoxidase activity was evident in samples containing Kat $A$, we were unable to detect any peroxidase activity. The catalase from $C$. jejuni appears, therefore, to be both structurally and enzymically similar to bacterial hydroperoxidases (von Ossowski et al., 1993). Furthermore, since only one protein band corresponding to catalase activity, and no bands of peroxidase activity, was detected in cell lysates from $C$. jejuni, it is possible that the hydroperoxidase activity encoded by kat $A$ is the only catalase possessed by this strain. We cannot, however, exclude the possibility that this strain contains additional inducible catalases that are not expressed under the microaerophilic conditions used to culture the cells. If this was the case though we would have expected to identify these catalases in our complementation studies.

The catalase gene was expressed at high levels in E. coli in the absence of the lac promoter inducer IPTG and independently of the orientation of the inserted DNA (data not shown), suggesting that expression in E. coli is directed by sequences present on the cloned $C$. jejuni DNA. In this respect, we have identified a region upstream of the catalase structural gene with homology to the E. coli consensus Fur-binding site. Although further experimentation is needed to determine whether irondependent regulation of the $C$. jejuni kat $A$ gene occurs, it is notable that Fur-binding sites have been identified upstream of another gene whose product is involved in oxidative stress resistance, namely superoxide dismutase (Purdy \& Park, 1994; Pesci et al., 1994). In addition, it is likely that $C$. jejuni has the appropriate mechanisms to facilitate iron-dependent Fur-regulation since a gene encoding a potential iron-responsive Fur-binding regulatory protein has recently been identified (Wooldridge $e t$ al., 1994).

The strain $C$. jejuni NCTC 11351, from which kat $A$ was originally cloned, has proven refractory to the introduction of recombinant DNA either by electroporation or natural transformation and was, therefore, an unsuitable host for the construction of catalase mutants via gene replacement. We chose, therefore, to assess whether it was possible to use the $C$. jejuni derived kat $A$ sequence to generate isogenic mutants by allelic exchange in a closely related species, namely $C$. coli. Following the introduction of the disrupted $C$. jejuni kat $A$ sequence into $C$. coli via natural transformation both $\mathrm{Kat}^{-}$and $\mathrm{Kat}^{+}$clones were isolated. Genetic and enzymic analysis of a $\mathrm{Kat}^{-}$tetracycline-resistant $C$. coli clone confirmed that allelic exchange had occurred between the DNA sequences of different origin. It is interesting to note that the process of homologous recombination, which apparently mediated the allelic exchange, occurred even in the absence of complete homology. Partial sequence analysis (data not shown) has shown the $C$. coli kat $A$ gene to be $92 \%$ identical to that from $C$. jejuni.

Catalase is thought to provide protection against oxidative stress by converting $\mathrm{H}_{2} \mathrm{O}_{2}$ to $\mathrm{H}_{2} \mathrm{O}$ and $\mathrm{O}_{2}$. To establish a role for catalase in the oxidative stress resistance of Campylobacter the resistance of the catalase-deficient isogenic mutant of $C$. coli to $\mathrm{H}_{2} \mathrm{O}_{2}$ was assessed in comparison to the wild-type. The $\mathrm{Kat}^{-}$mutant appeared to be much more sensitive to $\mathrm{H}_{2} \mathrm{O}_{2}$ than the parental strain. Furthermore, the sensitivity of $\mathrm{CK} 100$ to $\mathrm{H}_{2} \mathrm{O}_{2}$ appeared to be a consequence of its failure to detoxify this molecule, since more than $60 \%$ of the $\mathrm{H}_{2} \mathrm{O}_{2}$ persisted throughout the duration of the experiment. In contrast, wild-type cells were able to reduce the concentration of $\mathrm{H}_{2} \mathrm{O}_{2}$ to undetectable levels within just $5 \mathrm{~min}$ of exposure. In view of the persistence of $\mathrm{H}_{2} \mathrm{O}_{2}$ in the presence of the $\mathrm{Kat}^{-}$ mutants, the death of cells is perhaps not surprising since $\mathrm{H}_{2} \mathrm{O}_{2}$ diffuses across membranes and damages a variety of cellular targets (Farr \& Kogoma, 1991). Although it is not possible to rule out the possibility that the disrupted kat $A$ sequence has a polar effect on the expression of downstream genes, it seems very likely that the differential in the $\mathrm{H}_{2} \mathrm{O}_{2}$ sensitivity of the mutant compared to the wild-type strain is attributable to the absence of catalase.

As part of the defence mechanism which protects cells against oxidative damage, catalase is likely to play a crucial role in the survival of campylobacters in aerobic environments in which $\mathrm{H}_{2} \mathrm{O}_{2}$ may arise in the course of aerobic metabolism. In addition, it has been postulated that catalases might be an important means for bacterial pathogens to survive the oxidative bursts generated by eukaryotic inflammatory cells (Mandell, 1975; Haas \& Goebel, 1992). The genetic analysis of the gene encoding the catalase from $C$. jejuni and the characterization of an isogenic catalase-deficient mutant of $C$. coli may represent an important first step in establishing a role for this enzyme in the physiology and virulence of these clinically important pathogens.

\section{ACKNOWLEDGEMENTS}

We are grateful to P. C. Loewen and D. E. Taylor for the generous gifts of bacterial strains. We would also like to thank J. H. Dickinson for her help with nucleotide sequencing. We thank the Ministry of Agriculture, Fisheries and Foods for financial support for this work.

\section{REFERENCES}

Belland, R. J. \& Trust, T. J. (1982). Deoxyribonucleic acid sequence relatedness between members of the genus Campylobacter. J Gen Microbiol 128, 2515-2522. 
Bishai, W. R., Smith, H. O. \& Barcak, G. J. (1994). A peroxide/ ascorbate-inducible catalase from Haemopbilus influenzae is homologous to the Escherichia coli katE gene product. $J$ Bacteriol 176, 2914-2921.

Bol, D. K. \& Yasbin, R. E. (1991). The isolation, cloning, and identification of a vegetative catalase gene from Bacillus subtilis. Gene 109, 31-37.

Claiborne, A. \& Fridovich, I. (1979). Purification of the o-dianisidine peroxidase from Escherichia coli B. J Biol Chem 254, 4245-4252.

DeShazer, D., Wood, G. E. \& Friedman, R. L. (1994). Molecular characterization of catalase from Bordetella pertussis: identification of the kat $A$ promoter in an upstream insertion sequence. Mol Microbiol 14, 123-130.

Devereux, J., Haeberli, P. \& Smithies, O. (1984). A comprehensive set of sequence analysis programs for the VAX. Nucleic Acids Res 12, 387-395.

Dickinson, J. H., Grant, K. A. \& Park, S. F. (1995). Targeted and random mutagenesis of the Campylobacter coli chromosome using integrational plasmid vectors. Curr Microbiol (in press).

Dower, W. J., Miller, J. F. \& Ragsdale, C. W. (1988). High efficiency transformation of E. coli by high voltage electroporation. Nucleic Acids Res 16, 6127-6145.

Farr, S. B. \& Kogoma, T. (1991). Oxidative stress responses in Escherichia coli and Salmonella typhimurium. Microbiol Rev 55, 561-585.

Gold, L. (1988). Post-transcriptional regulatory mechanisms in Escherichia coli. Annu Rev Biochem 57, 199-233.

Griffiths, P. L. \& Park, R. W. A. (1990). Campylobacters associated with human diarrhoeal disease. J Appl Bacteriol 69, 281-301.

Haas, A. \& Goebel, W. (1992). Microbial strategies to prevent oxygen dependent killing. Free Radical Res Commun 16, 137-157.

Hawley, D. K. \& McClure, W. R. (1983). Compilation and analysis of Escherichia coli DNA promoter sequences. Nucleic Acids Res 11, 2237-2255.

Hoffman, P. S., George, H. A., Kreig, N. R. \& Smibert, R. M. (1979a). Studies of the microaerophilic nature of Campylobacter fetus subsp. jejuni. I. Physiolological aspects of enhanced aerotolerance. Can J Microbiol 25, 1-7.

Hoffman, P. S., George, H. A., Kreig, N. R. \& Smibert, R. M. (1979b). Studies of the microaerophilic nature of Campylobacter fetus subsp. jejuni. II. Role of exogenous superoxide anions and hydrogen peroxide. Can J Microbiol 25, 8-16.

Humphrey, T. J. (1992). Campylobacter jejuni: some aspects of epidemiology, detection and control. Brit Food J 94, 21-25.

Jones, D. M., Sutcliffe, E. M., Rios, R., Fox, A. J. \& Curry, A. (1993). Campylobacter jejuni adapts to aerobic metabolism in the environment. J Med Microbiol 38, 145-150.

Laemmli, U. K. (1970). Cleavage of structural proteins during the assembly of the head of bacteriophage T4. Nature 227, 680-685.

de Lorenzo, V., Wee, S., Herrero, W. \& Neilands, J. B. (1987). Operator sequences of the aerobactin operon of plasmid ColV-K30 binding the ferric uptake regulation (fur) repressor. J Bacteriol 169 , 2624-2630.

Mandell, G. L. (1975). Catalase, superoxide dismutase, and virulence of Stapbylococcus aureus: in vitro and in vivo studies with emphasis on staphylococcal-leucocyte interaction. J Clin Invest 55, 561-566.

Maniatis, T., Fritsch, E. F. \& Sambrook, J. (1982). Molecular Cloning: a Laboratory Manual. Cold Spring Harbor, NY: Cold Spring Harbor Laboratory.

Mulvey, M. R., Sorby, P. A., Triggs-Raine, B. L. \& Loewen, P. C. (1988). Cloning and physical characterization of kat $E$ and kat $F$, required for catalase HPII expression in Eschericbia coli. Gene 73, $337-345$.

von Ossowski, I., Mulvey, M. R., Leco, P. A., Borys, A. \& Loewen, P. C. (1991). Nucleotide sequence of Escherichia coli kat $E$ which encodes catalase HPII. J Bacteriol 173, 514-520.

von Ossowski, I., Hausner, G. \& Loewen, P. C. (1993). Molecular evolutionary analysis based on the amino acid sequence of catalase. $J$ Mol Evol 37, 71-76.

Pesci, E. C., Cottle, D. L. \& Pickett, C. L. (1994). Genetic, enzymatic, and pathogenic studies of the iron superoxide dismutase of Campylobacter jejuni. Infect Immun 62, 2687-2695.

Pick, E. \& Keisari, Y. (1980). A simple colorimetric method for the measurement of hydrogen peroxide produced by cells in culture. $J$ Immunol Methods 38, 161-170.

Pitcher, D. G., Saunders, N. A. \& Owen, R. J. (1989). Rapid extraction of bacterial genomic DNA with guanidium thiocyanate. Lett Appl Microbiol 8, 151-156.

Purdy, D. \& Park, S. F. (1994). Cloning, nucleotide sequence and characterization of a gene encoding superoxide dismutase from Campylobacter jejuni and Campylobacter coli. Microbiology 140, 12031208.

Sha, Z., Stabel, T. J. \& Mayfield, J. E. (1994). Brucella abortus catalase is a periplasmic protein lacking a standard signal sequence. $J$ Bacteriol 176, 7375-7377.

Tauxe, R. V. (1992). Epidemiology of Campylobacter jejuni in the United States and other industrialised nations. In Campylobacter jejuni: Current Status and Future Trends, pp. 9-19. Edited by I. Nachamkin, M. J. Blaser \& L. S. Tompkins. Washington, DC: American Society for Microbiology.

Vercellone, P. A., Smibert, R. M. \& Kreig, N. R. (1990). Catalase activity in Campylobacter jejuni: comparison of a wild-type strain with an aerotolerant variant. Can J Microbiol 36, 449-451.

Wang, Y. \& Taylor, D. E. (1990). Natural transformation in Campylobacter species. J Bacteriol 172, 949-955.

Wayne, L. G. \& Diaz, A. G. (1986). A double staining method for differentiating between two classes of mycobacterial catalase in polyacrylamide gels. Anal Biochem 157, 89-92.

Woodbury, W., Spencer, A. K. \& Stahman, M. A. (1971). An improved procedure using ferricyanide for detecting catalase isoenzymes. Anal Biochem 44, 301-305.

Wooldridge, K. G., Williams, P. H. \& Ketley, J. M. (1994). Ironresponsive genetic regulation in Campylobacter jejuni: cloning and characterization of a fur homolog. $J$ Bacteriol 176, 5852-5856.

Received 16 December 1994; revised 24 February 1995; accepted 1 March 1995. 